\title{
Allelopathic Effects of Ludwigia decurrens and L. adscendens subsp. diffusa on Germination, Seedling Growth and Yield of Corchorus olitorious L.
}

\author{
Ayobola Moninuola SAKPERE, Matthew OZIEGBE, Idowu Arinola BILESANMI \\ Obafemi Awolowo University, Department of Botany, Ile-Ife, Nigeria; matthewoziegbe@yahoo.com (corresponding author)
}

\begin{abstract}
This study examined the allelopathic effect of Ludwigia decurrens and L. adscendens exudates on germination, seedling growth (hypocotyl and radicle elongation), seedling mortality, vegetative growth and reproductive yield of Corchorus olitorious. Ludwigia decurrens, L. adscedens exudates and tap water (control) were applied to seeds of Corchorus olitorious over a period of 15 days and to 3 weeks old seedling for a period of 4 weeks. Ludwigia exudates had no inhibitory effect on the germination percentage of $C$. olitorious, but the exudates from the two Ludwigia spp. induced mortality rate of the 15 day old seedlings (control: $5.00 \%, L$. decurrens: $17.50 \%, L$. adscendens: 26.88\%) and a significant decrease in seedling elongation (hypocotyl and radicle length) of C. olitorious. For the vegetative growth experiment, results showed that the stem length, stem fresh weight and leaf area of $C$. olitorious were significantly inhibited during week $6(\mathrm{P}<0.05)$ by $L$. decurrens and $L$. adscendens exudates. For reproductive yield experiment, number of pods per plant was significantly reduced on week 11 . The high percentage mortality rate observed in seedlings might be an important factor in reducing seedling survival of Corchorus olitorious in habitats where the two Ludwigia spp are dominant.
\end{abstract}

Keywords: Ludwigia, allelopathy, Corchorus olitorious, seedling growth, vegetative growth, reproductive yield

\section{Introduction}

Allelopathy refers to the production and exudation of compounds, including secondary metabolites, harmful to other species or their functions and influencing the growth and development of Agricultural and Biological systems (Rice, 1984; Elmore and Abendroth, 2007). These allelopathic effects are due to inhibitory substances (allelochemicals) that are released directly from living plants into the environment through root exudation, leaching, volatilization, and passively liberated through the decomposition of plant residues (Rice, 1984). Many of the allelochemicals are water soluble substances which are affected by several environmental factors (Reigosa et al., 1999). Plants can influence each other by allelopathy which is usually harmful (Boonitee and Ritdhit, 1984) while sometimes the effect is beneficial (Newman and Andrews, 1973). There is much evidence that allelochemicals liberated from certain weeds into the soil reduce crop growth (Rice, 1979; Putnam and Tang, 1986). Stinson et al. (2006) reported that allelopathy has been demonstrated to play a crucial role in forests influencing the composition of the vegetation growth, while also providing explanation for the patterns of forest regeneration. Allelopathy is rather well documented for a variety of terrestrial plants, but the information on how widespread this phenomenon is among aquatic plant is scanty (Gopal and Goel, 1993).
Ludwigia taxa have been classified among the 200 most aggressive world plant invaders (Cronk and Fuller, 1995). The genus Ludwigia is a member of the family Onagraceae which are flowering plants belonging to the Order Myrtales, comprising 21 genera concentrated in the temperate region of the New World. The family (Onagraceae) is characterized by flowers with parts mostly on the plan of four (four sepals, four petals, four or eight stamens) and the ovary is inferior (Chen et al., 1992). The family includes about 640-650 species of herbs, shrubs, and trees in 20-24 genera. The family is widespread on every continent from boreal to tropical regions (Ford and Gottlieb, 2007). The genus Ludwigia (primerose-willow) contains 82 species (Zardini et al, 1991) and can be found in wet places, especially in warmer parts of the Eastern and the Western hemisphere. Most Ludwigia species occur in wet places while a few are predominantly aquatic, ranging from annual herbs to large shrubs (Wogu and Ugborogho, 2000). The large tolerance and adaptation of these taxa to the variations of hydrological and climatic conditions, as well as their strong ability to colonize make them remarkable competitors. Their proliferation induces a silting up of aquatic ecosystems and slowing down of water circulation (Dutartre, 1988).

Members of the section Oligospermum (Ludwigia peploides (Kunth)) Raven and L. glandiflora (Michaux) Greuter and Burdet) to which L. adscendens belong have been reported to exhibit allelopathy (Dandelot et al., 2008). L. 
76

adscendens (Linn) is a perennial herb, creeping over mud rooting at the nodes, or floating and matting, common across the region from Senegal to Southern Nigeria, and generally widespread over the rest of the Tropical Africa, and into the Near East. It is reported to be a weed of rice paddy in The Gambia (Burkill, 1997) and also known for its antibacterial activity (Firoj et al., 2005). In aquatic habitats (Fadama) Ile-Ife and its surroundings where vegetables are grown, $L$. decurrens which is an erect annual herb have been observed to form monotypic stands serving as threats to cultivated plants in aquatic habitat.

The genus Corchorus is a member of the family Tiliaceae, native to tropical and subtropical regions throughout the World (Nath, 1976). Corchorus olitorious L., commonly called jute, are tall plants, usually annual herbs. The leaves are altenate, simple, lanceolate, with finely serrated or lobed margin. The flowers are hermaphrodite, and are pollinated by insects. The fruit is a multi-seeded capsule (Norman, 1972). The plant prefers light (Sandy), medium (loamy), and heavy (clay) soils (Epenhuijsen, 1974). It cannot tolerate shady environments and requires moist soil. Seeds of $C$. olitorious (Tossa jute) are small in size, grayish in colour and weight about 1 gram per 1000 seeds. Fresh leaves of Corchorus olitorious are a rich source of vitamin $\mathrm{A}$ and $\mathrm{C}$. The leaves are used in the treatment of chronic cystitis, gonorrhea, and for toothache (Hillocks, 1998). A cold infusion is used as a tonic to restore the appetite and strength (Sharaf and Negm, 2005). The seeds are used for fever, as a purgative and possess broad antibacterial properties (Pall et al., 2006). Jute leaves are consumed in various parts of the world. It is a popular vegetable in West Africa. Corchorus olitorius is an important pot herb in Nigeria. Its cultivation spans both the rainy and the dry seasons in $\mathrm{Ni}$ geria. In the dry season, irrigation facility is paramount for successful cultivation. However, because of the peculiarity of annual fadama (wetland) cultivation the flora of the cultivated land tends to become predicable and poorly diversified with time. Very few weed species predominate in such cropping systems (Oguyemi et al., 2005). This study investigated the allelopathic effects of Ludwigia decurrens and $L$. adscendens exudates on the germination, mortality, seedling growth (radicle and hypocotyl elongation), vegetative and reproductive yield of Corchorus olitorious.

\section{Materials and methods}

In March 2009, matured flowering plants of Ludwigia adscendens and $L$. decurrens were randomly collected from the wild population along Ede road in Ile Ife and Ilesa. Each species of Ludwigia collected was rinsed in clean water to remove debris attached to the roots. Ten plants both of Ludwigia spp. were placed into two 10 litres plastic buckets filled with tap water and were placed in the open air for seven days before the plant exudates were used. Tap water was added constantly to maintain a constant volume. Corchorus olitorious seeds were purchased from Grow well
Agro services stores, Ile-Ife. Twenty seeds of $C$. olitorious were sown in petridishes of $8 \mathrm{~cm}$ in diameter lined with Whatman Filter paper no. 1. There were four replicates for each of the treatments to be tested (control (tap water), Ludwigia adscendens exudates water, $L$. decurrens exudates water). $2 \mathrm{mls}$ of tap water, $2 \mathrm{mls}$ of Ludwigia adscendens exudates water and $2 \mathrm{mls}$ of $L$. decurrens exudates were added daily to each Petridishes of the treatments. For each of the treatments number of germinated seeds and seedling mortality rate were recorded daily for a period of 15 days. Seeds were considered to have germinated at the emergence of the radicle. On the 15 th day five seedlings per treatment were randomly selected from each Petridishes and the radicle and hypocotyl length were measured.

Seeds of Corchorus olitorious were sown into a nursery of plastic bowls with the diameter of $23 \mathrm{~cm}$ and 12 $\mathrm{cm}$ in depth which were perforated at the base to allow good drainage and filled with top soil and watered regularly with tap water. After 2 weeks, germinated plants were transplanted into 12 plastic bowls filled with top soil, at the rate of 10 plants per bowl. There were four replicates for each of the treatments to be tested with tap water (control), Ludwigia adscendens exudates water and $L$. decurrens exudates water. Plants were allowed to stabilize for one week. $250 \mathrm{mls}$ of tap water, $250 \mathrm{mls}$ each of Ludwigia adscendens and $L$. decurrens exudates water were added every two days to each plastic bucket of the treatments for a period of four weeks. On a weekly basis beginning at the end of the fourth week after germination, destructive analyses were carried out on each treatment by randomly harvesting five plants per treatment. Plants were properly labeled and taken to the laboratory for data collection. The morphological characters scored include the following: Plant Stem Length, Plant Root length, Number of leaves per plant, Leaf Length and breadth, Leaf Area. The Fresh weights (F. W.) and Dry Weights (D. W.) of Stems, Root and Leaves of five plants from each treatment were obtained by weighing each plant on Mettlers Toledo (PB 153) electronic balance immediately after harvest. Each of the plants was package in separate envelopes and dried at $80^{\circ} \mathrm{C}$ in a Gallenkamp (model $1 \mathrm{H}-150$ ) incubator for two days and weigh to obtain Dry Weights (D. W.). At the end of the $11^{\text {th }}$ week five plants were selected from each treatment and the number of pods per plant was recorded. The fresh and dry weights of pods per plant were also determined. Data obtained from germination experiment, destructive analysis and yield experiment during the course of this experiment were subjected to one way analysis of variance and means were separated with Duncan's multiple range test (DMTR), using system analysis software (SAS) version 9.2.

\section{Results}

Hypocotyl length of Corchorus olitorious control was significantly longer than that of the two treatments (L.de- 
Tab. 1. Mean hypocotyl and radicle length, percentage germination and mortality of Corchorus olitorious seeds in the treatments

\begin{tabular}{ccccc}
\hline Treat-ments & $\begin{array}{c}\text { Hypocotyl } \\
\text { Length } \\
\text { (At day 15) }\end{array}$ & $\begin{array}{c}\text { Radicle } \\
\text { Length } \\
\text { (At day 15) }\end{array}$ & $\begin{array}{c}\text { Percentage } \\
\text { Germination }\end{array}$ & $\begin{array}{c}\text { Percentage } \\
\text { Mortality } \\
\text { (At day 15) }\end{array}$ \\
\hline $\begin{array}{c}\text { Control } \\
\text { L. }\end{array}$ & $2.976^{\mathrm{a}}$ & $1.82^{\mathrm{a}}$ & $50.00^{\mathrm{a}}$ & $5.00^{\mathrm{b}}$ \\
$\begin{array}{c}\text { decurrens } \\
\text { L. }\end{array}$ & $2.01^{\mathrm{b}}$ & $1.26^{\mathrm{b}}$ & $59.38^{\mathrm{a}}$ & $17.50^{\mathrm{a}}$ \\
adscedens & $2.17^{\mathrm{b}}$ & $1.69^{\mathrm{ab}}$ & $53.13^{\mathrm{a}}$ & $26.88^{\mathrm{a}}$ \\
\hline
\end{tabular}

${ }^{*}$ Values in each column followed by the same letter are not significantly different at $\mathrm{P}<0.05$

currens and $L$. adscendens exudates). Radicle length of $C$. olitorious control was significantly longer than that of the two treatments, but with $L$. decurrens having more effect than $L$. adscedens. Percentage germination of $C$. olitorious control was not significantly different from the two treat- rens exudates (Tab. 4 and 5). The Root length of Corchorus olitorious control and the two treatments were not significantly different at week 4, 5 and 7 (Tab. 2, 3 and 5). At week 6 , the root length was significantly reduced by the treatments (Tab. 4). Numbers of leaves of $C$. olitorious from week 4 to week 7 for all treatments were not significantly different (Tab. 2, 3, 4 and 5).

Stem F. W. of C. olitorious control and the two treatments were not significantly different at week 4 and week 5 (Tab. 2 and 3). At week 6 and week 7 stem fresh weight of C. olitorious plants treated with Ludwigia exudates were significantly lower than the control plants but with more effect at week 7 in L. decurrens (Tab. 4 and 5). Stem D. $\mathrm{W}$. in the control and the two treatments were not significantly different from week 4 to 7 (Tab. 2, 3, 4 and 5).

Root F. W. of $C$. olitorious control and the two treatments were not significantly different at week 4 and 7 (Tab. 2 and 5). Root F. W. of C. olitorious control was significantly higher than that of the two treatments at week 5

Tab. 2. Effect of Ludwigia decurrens and L. adscendens exudates on vegetative parameters of Corchorus olitorious at week 4

\begin{tabular}{ccccccccccc}
\hline \multirow{2}{*}{ Treatment } & $\begin{array}{c}\text { Stem } \\
\text { Length }\end{array}$ & $\begin{array}{c}\text { Root } \\
\text { Length }\end{array}$ & $\begin{array}{c}\text { No.of } \\
\text { Leaves }\end{array}$ & $\begin{array}{c}\text { Stem } \\
\text { F. W. }\end{array}$ & $\begin{array}{c}\text { Stem } \\
\text { D. W. }\end{array}$ & $\begin{array}{c}\text { Root } \\
\text { F. W. }\end{array}$ & $\begin{array}{c}\text { Root } \\
\text { D. W. }\end{array}$ & $\begin{array}{c}\text { Leaf } \\
\text { F. W. }\end{array}$ & $\begin{array}{c}\text { Leaf } \\
\text { D. W. }\end{array}$ & Leaf Area \\
\hline Control & $6.61^{\mathrm{a}}$ & $4.66^{\mathrm{a}}$ & $5.70^{\mathrm{a}}$ & $0.12^{\mathrm{a}}$ & $0.02^{\mathrm{a}}$ & $0.05^{\mathrm{a}}$ & $0.01^{\mathrm{a}}$ & $0.64^{\mathrm{a}}$ & $0.05^{\mathrm{a}}$ & $13.55^{\mathrm{b}}$ \\
L. decurrens & $8.23^{\mathrm{a}}$ & $4.74^{\mathrm{a}}$ & $5.60^{\mathrm{a}}$ & $0.19^{\mathrm{a}}$ & $0.02^{\mathrm{a}}$ & $0.09^{\mathrm{a}}$ & $0.02^{\mathrm{a}}$ & $0.38^{\mathrm{a}}$ & $0.07^{\mathrm{a}}$ & $14.56^{\mathrm{ab}}$ \\
L. adscendens & $7.55^{\mathrm{a}}$ & $4.50^{\mathrm{a}}$ & $6.00^{\mathrm{a}}$ & $0.18^{\mathrm{a}}$ & $0.02^{\mathrm{a}}$ & $0.10^{\mathrm{a}}$ & $0.02^{\mathrm{a}}$ & $0.38^{\mathrm{a}}$ & $0.06^{\mathrm{a}}$ & $17.21^{\mathrm{a}}$ \\
\hline
\end{tabular}

*Values in each column followed by the same letter are not significantly different at $\mathrm{P}<0.05$

ments. Percentage mortality $C$. olitorious in the control experiment was significantly lower than that of the two treatments (Tab. 1). and 6, but with more effect at week 6 in L. decurrens (Tab. 3 and 4 ). Root D. W. of C. olitorious control and the two treatments were not significantly different at week 4,5 and

Tab. 3. Effect of Ludwigia decurrens and L. adscendens exudates on vegetative parameters of Corchorus olitorious at week 5

\begin{tabular}{|c|c|c|c|c|c|c|c|c|c|c|}
\hline Treatment & $\begin{array}{c}\text { Stem } \\
\text { Length }\end{array}$ & $\begin{array}{c}\text { Root } \\
\text { Length }\end{array}$ & $\begin{array}{l}\text { No. of } \\
\text { Leaves }\end{array}$ & $\begin{array}{l}\text { Stem } \\
\text { F.W. }\end{array}$ & Stem D.W. & Root F.W. & $\begin{array}{l}\text { Root } \\
\text { D.W. }\end{array}$ & Leaf F.W. & $\begin{array}{l}\text { Leaf } \\
\text { D.W. }\end{array}$ & Leaf Area \\
\hline Control & $12.47^{a}$ & $5.10^{a}$ & $7.90^{a}$ & $0.36^{a}$ & $0.04^{\mathrm{a}}$ & $0.28^{a}$ & $0.04^{a}$ & $0.51^{\mathrm{a}}$ & $0.13^{\mathrm{a}}$ & $14.14^{b}$ \\
\hline L. decurrens & $9.44^{\mathrm{a}}$ & $4.65^{a}$ & $6.90^{\mathrm{a}}$ & $0.33^{a}$ & $0.03^{\mathrm{a}}$ & $0.15^{\mathrm{b}}$ & $0.04^{\mathrm{a}}$ & $0.63^{a}$ & $0.11^{a}$ & $14.84^{b}$ \\
\hline L. adscendens & $12.42^{a}$ & $4.45^{\mathrm{a}}$ & $7.60^{\mathrm{a}}$ & $0.41^{\mathrm{a}}$ & $0.04^{\mathrm{a}}$ & $0.14^{\mathrm{b}}$ & $0.04^{a}$ & $0.73^{\mathrm{a}}$ & $0.13^{\mathrm{a}}$ & $19.88^{a}$ \\
\hline
\end{tabular}

${ }^{*}$ Values in each column followed by the same letter are not significantly different at $\mathrm{P}<0.05$

The stem length of Corchorus olitorious control and the two treatments were not significantly different at week 4 and 5 (Tab. 2 and 3). At week 6 and 7, the treatments significantly reduced the stem length, more evident with $L$. adscendens exudates, having more effect than $L$. decur-
7 (Tab. 2, 3 and 5). Root D. W. of C. olitorious control was significantly higher than that of the two treatments at week 6 (Tab. 4).

Leaf F. W. and D. W. of C. olitorious and control and the two treatments were not significantly different at week

Tab. 4. Effect of Ludwigia decurrens and L. adscendens exudates on vegetative parameters of Corchorus olitorious at week 6

\begin{tabular}{ccccccccccc}
\hline Treatment & \multirow{2}{*}{ Stem Length } & $\begin{array}{c}\text { Root } \\
\text { Length }\end{array}$ & $\begin{array}{c}\text { No. of } \\
\text { Leaves }\end{array}$ & $\begin{array}{c}\text { Stem } \\
\text { F. W. }\end{array}$ & $\begin{array}{c}\text { Stem } \\
\text { D. W. }\end{array}$ & $\begin{array}{c}\text { Root } \\
\text { F. W. }\end{array}$ & $\begin{array}{c}\text { Root } \\
\text { D. W. }\end{array}$ & $\begin{array}{c}\text { Leaf } \\
\text { F. W. }\end{array}$ & $\begin{array}{c}\text { Leaf } \\
\text { D. W. }\end{array}$ & Leaf Area \\
\hline Control & $23.19^{\mathrm{a}}$ & $11.06^{\mathrm{a}}$ & $9.10^{\mathrm{a}}$ & $1.18^{\mathrm{a}}$ & $0.19^{\mathrm{a}}$ & $0.43^{\mathrm{a}}$ & $0.13^{\mathrm{a}}$ & $1.54^{\mathrm{a}}$ & $0.31^{\mathrm{a}}$ & $18.51^{\mathrm{a}}$ \\
L. decurrens & $16.020^{\mathrm{b}}$ & $7.42^{\mathrm{b}}$ & $8.10^{\mathrm{a}}$ & $0.60^{\mathrm{b}}$ & $0.10 \mathrm{a}$ & $0.25^{\mathrm{b}}$ & $0.08^{\mathrm{b}}$ & $0.93^{\mathrm{b}}$ & $0.19^{\mathrm{b}}$ & $14.17^{\mathrm{b}}$ \\
L. adscendens & $15.31^{\mathrm{b}}$ & $5.01^{\mathrm{c}}$ & $9.50^{\mathrm{a}}$ & $0.60^{\mathrm{b}}$ & $0.14^{\mathrm{a}}$ & $0.33^{\mathrm{ab}}$ & $0.07^{\mathrm{b}}$ & $0.95^{\mathrm{b}}$ & $0.17^{\mathrm{b}}$ & $19.80^{\mathrm{a}}$ \\
\hline
\end{tabular}

*Values in each column followed by the same letter are not significantly different at $\mathrm{P}<0.05$ 
Tab. 5. Effect of Ludwigia decurrens and L. adscendens exudates on vegetative parameters of Corchorus olitorious at week 7

\begin{tabular}{ccccccccccc}
\hline \multirow{2}{*}{ Treatment } & \multirow{2}{*}{ Stem Length } & $\begin{array}{c}\text { Root } \\
\text { Length }\end{array}$ & $\begin{array}{c}\text { No. of } \\
\text { Leaves }\end{array}$ & $\begin{array}{c}\text { Stem } \\
\text { F. W. }\end{array}$ & $\begin{array}{c}\text { Stem } \\
\text { D. W. }\end{array}$ & $\begin{array}{c}\text { Root } \\
\text { F. W. }\end{array}$ & $\begin{array}{c}\text { Root } \\
\text { D. W. }\end{array}$ & $\begin{array}{c}\text { Leaf } \\
\text { F. W. }\end{array}$ & $\begin{array}{c}\text { Leaf } \\
\text { D. W. }\end{array}$ & Leaf Area \\
\hline Control & $24.92^{\mathrm{a}}$ & $7.27^{\mathrm{a}}$ & $10.00^{\mathrm{a}}$ & $1.39^{\mathrm{a}}$ & $0.23^{\mathrm{a}}$ & $0.43^{\mathrm{a}}$ & $0.11^{\mathrm{a}}$ & $1.75^{\mathrm{a}}$ & $0.39^{\mathrm{a}}$ & $20.75^{\mathrm{a}}$ \\
L. decurrens & $22.14^{\mathrm{ab}}$ & $6.80^{\mathrm{a}}$ & $10.30^{\mathrm{a}}$ & $0.97 \mathrm{~b}$ & $0.18^{\mathrm{a}}$ & $0.30^{\mathrm{a}}$ & $0.10^{\mathrm{a}}$ & $1.46^{\mathrm{a}}$ & $0.35^{\mathrm{a}}$ & $20.71^{\mathrm{a}}$ \\
L. adscendens & $20.21^{\mathrm{b}}$ & $5.23^{\mathrm{a}}$ & $11.10^{\mathrm{a}}$ & $0.99 \mathrm{ab}$ & $0.15^{\mathrm{a}}$ & $0.36^{\mathrm{a}}$ & $0.10^{\mathrm{a}}$ & $1.64^{\mathrm{a}}$ & $0.34^{\mathrm{a}}$ & $20.91^{\mathrm{a}}$ \\
\hline
\end{tabular}

*Values in each column followed by the same letter are not significantly different at $\mathrm{P}<0.05$

4, 5 and 7 (Tab. 2, 3 and 5). At week 6, Leaf F. W. and D. W of $C$. olitorious control were significantly higher than that of the two treatments (Tab. 4). Leaf Area of C. olitorious treated with $L$. adscendens exudates was significantly higher than that of $C$. olitorious control and $C$. olitorious treated with $L$. adscendens at week 4 (Tab. 2). Leaf Area of $C$. olitorious control and the two treatments were not significantly different at week 5 and 7 (Tab. 3 and 5).

Tab. 6. Effect of Ludwigia decurrens and L. adscendens exudates on reproductive yield of Corchorus olitorious

\begin{tabular}{cccc}
\hline Treatment & $\begin{array}{c}\text { Fresh Pod } \\
\text { Weight }\end{array}$ & $\begin{array}{c}\text { Dry Pod } \\
\text { Weight }\end{array}$ & $\begin{array}{c}\text { Number of Pods } \\
\text { per Plant }\end{array}$ \\
\hline Control & $2.48^{\mathrm{a}}$ & $0.58^{\mathrm{a}}$ & $4.40^{\mathrm{a}}$ \\
L. decurrens & $1.32^{\mathrm{a}}$ & $0.26^{\mathrm{a}}$ & $2.60^{\mathrm{ab}}$ \\
L. adscendens & $1.59^{\mathrm{a}}$ & $0.28^{\mathrm{a}}$ & $2.40^{\mathrm{b}}$ \\
\hline
\end{tabular}

${ }^{*}$ Values in each column followed by the same letter are not significantly different at $\mathrm{P}<0.05$

Fresh and dry weight of pods from the control plants and the two treatments were not significantly different. However, number of pods per plant in the control was significantly higher than that of the two treatments with L. adscendens treatment having the lowest number of pods (Tab. 6).

\section{Discussion}

Allelopathic effect of one plant on another plant could be through the inhibition of seed germination, for example, aqueous extract of root of Helianthus annus that delay and inhibits the germination and seedling growth of linseed (Linum usitatissium L.) and mustard (Brassica juncea L.) (Narwal et al., 2002). The two Ludwigia spp. exhibited similar effects on the seeds of C. olitorious. Ludwigia decurrens and $L$. adscendens exudates have had no inhibitory effect on the percentage germination of seeds of Corchorus olitorious. This might be due to the fact that seeds protected by their teguments, seem less sensitive to allelochemicals than seedlings (Elakovich, 1999; Quayyum et al., 1999). A similar result was obtained by Brucker et al. (2003) who found that allelochemicals from the inflorenscence extract of Ambrosia artemisifolia did not significantly reduce the germination of seeds of Amaranthus hypochondriacus. Dandelot et al. (2008) reported a significant reduction in percentage germination of watercress and no reduction in lettuce germination when treated with $L$. pepliodes and $L$. grandiflora exudates.

The hypocotyl and radicle length of $C$. olitorious was inhibited by $L$. decurrens and $L$. adscendens exudates. The two treatments increased the mortality of $C$. olitorious seedlings at day 15 . This is similar to the findings of Dandelot et al. (2008) in which Ludwigia peploides and L. grandiflora reduce the seedling elongation and causes an increase in mortality of water lettuce during all season. Allelopathic effect could be concentration dependent as reported by Kayode and Ayeni (2009) when they examined the allelopathic effects of aqueous extracts from Sorghum stem and rice husks on the germination and growth of maize. The extracts brought about considerable inhibitions in the germination of maize seed and in the growth of radicle and plumule. In both extracts, the degree of inhibition increased with the increase of the concentrations of the extracts thus suggesting that the effects of the extracts were concentration dependent. The effect could also depend on the age of plant. (Otusanya et al., 2007) examined the susceptibility of Amaranthus cruentus Linn. to phytotoxic effects of Tithonia diversifolia (Hemsl) A. Results showed that the germination, growth parameters and fresh and dry matter production of Amaranthus cruentus were retarded by all four different aqueous extracts applied and the retardation was more pronounced on the older plants of Amaranthus cruentus. This explains the mild effects by Ludwigia exudates on most growth parameters of C. olitorious at later stage of development. The exudates of $L$. decurrens and L. adscendens were observed to retard the stem length of $C$. olitorious by the end of week 5 till the end of the experiment with more inhibitory effect being produced by $L$. adscendens exudates. Allelochemicals from Wedelia trilobata L. was also found to reduce the plant height of rice (Chengrong et al., 2005). The root length of $C$. olitorious was inhibited by $L$. decurrens exudates and $L$. adscendens exudates at week 6 with $L$. adscendens exudates producing more inhibitory effect by week 7 root lengths were similar to that of the control experiment. This may be due to the fact that the inhibition of the stem length at week 6 destabilized the root length, but by week 7 , the inhibitory effects of the exudates on the root length were outgrown.

The two treatments were first observed to have a stimulatory effect on the leaf area at the beginning of this experiment (week 4) till the end of the week 5, as the leaf area could be seen to be low in the control experiment and in 
$C$. olitorious treated with $L$. decurrens. But by week 6 , the leaf area were reduced in the two treatments and became similar to the control by the end of the seedling growth experiment. The inconsistent growth in the leaf area may affect the proper growth of plant since reduced leaf area could result in lower photosynthetic capacity for a plant and ultimately limit growth (Sin Clair, 1990; Federics and Comberato, 1995). The pod fresh weight and pod dry weight were similar to that of control in yield experiment, but the number of pod per plant were reduced in $C$. olitorious treated with $L$. decurrens and $L$. adscedens exudates. This may result in a decrease in seed, and production of C. olitorious spp. can be limited due to lack of seeds (Adebooye et al., 2005).

The mild inhibitory effect of Ludwigia exudates on three weeks seedling for the period of study might be as result of $C$. olitorious trying to withstand the concentration of the available allochemicals. According to Gross (2003) allochemicals released by donor oraganism into the water need to be sufficiently hydrophilic and reach their target organisms in effective concentration despite considerable dilution. The effect of Ludwigia exudates will be felt more on plants during the dry season when water level is low and many of them flourish in their habitats. The study of allelochemicals in Ludwigia will be complex because Ludwigia spp. synthesize tannins, trierpines, flavoniods, polyphenols, alkaloids, linoleic acids, saponins, etc (Ghani, 1998) that can in synergy exert either phytotoxic or allelopathic effects (Singhvi and Sharma, 1984). Allelopathic interactions can play a key role since they may alter physiological processes and thus influence the structure of communities (Rice, 1992; Bais et al., 2003; Inderjit and Duke, 2003).

In conclusion, exudates of both Ludwigia decurrens and $L$. adscendens inhibited early seedling growth of Corchorus olitorious, leading to high mortality of the young seedlings. But seedlings that were already established were not affected. Higher concentrations of Ludwigia exudates are likely to increase mortality rate of 15 day old seedling. Farmers are advised to cultivate the young seedlings of $C$. olitorious in control nurseries for the first two weeks of germination before transplanting them to the field, because plants will be strong enough to outgrow the effect of Ludwigia exudates at this age. There is the need for further studies to be carried out on identifying the inhibiting allelochemicals in the two Ludwigia spp. investigated.

\section{References}

Adebooye, O. C., S. A. Ajayi, J.J. Baidu-Forson and J. T. Opabode (2005). Seed constraint to cultivation and productivity. African Journal of Biotechnology 13:1480-1484.

Bais, H. P., R. Vepachedu, S. Gilory, R. M. Callaway and J. M. Vivanco (2003). Allelopathy and exotic plant invasion: from molecules and genes to species interactions. Sci. 301:3771380.
Boonitee, A. and P. Ritdhit (1984). Allelopathic effects of some weeds on munbean plants (Vigna radiata). Tropical weed science. 2:401-406.

Brucker, D. J., L. Anita and H. Zolotan (2003). Inhibitory effect of rage weed (Ambrosia artemissifolia L.) Inflorescence extracts on the germination of Amaranthus hypochondriacus L. and growth of two soil algae. Chemosphere 51:515-519.

Burkill, H. M. (1997). The useful plants of West Tropical Africa. Vol 4 Edition 2. Royal. Botanical Gardens. Kew.

Chen, C. J., P. C. Hoch and P. H. Raven (1992). Systematics of Epilobium (Onagraceae) in China. Syst. Bot. Monogr. 34:1209.

Chengrong, N., L. Shiming, Z. Rensen, M. Meihua, L. Huashou and L. Chuxia (2005). Allelopathic potential of Wedelia trilobata L. effects on germination, growth and physiological parameters of rice. Fourth World Congress on Allelopathy.

Cronk, Q. C. B. and J. L. Fuller (1995). Plant Invaders: The Threat to Natural Ecosystems. Chap. Hall, Lon.

Dandelot, S., C. Robles, N. Pech, A. Cazaubon and R. Verlaque (2008). Allelopathic potential of two invasive alien Ludwigia spp. Aquatic Botany 88:311-316.

Dutartre, A. (1988). Nuisances occasionnees per les plantes aquatiques imputable aux vegetaux. Analyses de cas. In Ann. ANPP, 15eme Conferences du COLUMA, Versailles, ANPP (Eds.), Paris.

Elakovich, S. D. (1999). Bioassays applied to allelopathic herbaceous vascular hydrophytes, p. 45-56. In: Principles and Practices in Plant Ecology: Allelochemical Interactions. Inderjit, Dakshini, K. M. and F. A. Einhellig (Eds.). CRC Press, Boca Raton.

Elmore, R. and L. Abendroth. (2007). Allelopathy: A cause for yield penalties in corn following corn. Dept. Agr. Int. Crop Mng.

Epenhuijsen, C. W. V. (1974). Growing native vegetables in Nigeria. F.A.O. Rome.

Firoj, A., M. S. T. Selin and J. A. Shilpbi (2005). Antibacterial activity of Ludwigia adscendens. Fitoterapia 76:473-475.

Ford, V. S. and L. D. Gottlieb (2007). Tribal relationships within Onagraceae. Seq. Syst. Bot. 32:348-356.

Ghani, A. (1998). Medicinal Plants of Bangladesh: Chemical Consitituents and Uses. Asiatic Society of Bangledesh, Dhaka. Gopal, B. and U. Goel (1993). Competition and allelopathy in aquatic plant communities. The Bot. Rev. 59:155-210.

Gross, E. M. ( 2003). Allelopathy of aquatic autotrophs. Critical Review in Plant Science 22:313-339.

Hillocks, R. J. (1998). The potential benefits of weeds with reference to small holder agriculture in Africa. Integrated Pest management Reviews 3:155-167.

Inderjit and S. O. Duke (2003). Ecophysiological aspects of allelopathy. Planta 217:529-539.

Kayode, J. and J. M. Ayeni. (2009). Allelopathic Effects Of Some Crop Residues on the Germination and Growth 
80 of Maize (Zea mays L). Pacific Journal of Science and Technology1:345-349.

Narwal, S. S., R. Palaniraj, S. C. Sati, L. S. Rawat and D. S. K. Rawat (2002). Allelopahtic effects of aqueous extracts of Sunflower (Helianthus annus L.) root on some winter oil seed crop. Geobies 29:225-228.

Nath, P. (1976). Vegetables for the region. Indian Council of Agriculture Research. New Dehli.

Newman, F. I. and R. E. Andrews (1973). Allelopathy among some British grassland species II. Influence of soaked exudates on phosphorus uptake. Journal of Ecology 65:399411.

Norman, A. Y. (1972). Tropical leaf vegetables in Ghana. World Crops 24:217-219.

Otusanya, O. O., O. J. Ilori and A. A. Adelusi (2007). Allelopathic effect of Tithonia diversifolia (Hemsl) A. Gray on the Germination and Growth of Amaranthus cruentus. Research Journal of Environmental Sciences 6:285-293.

Pall, D. K, M. Mandal, G. P. Senthilkumar and A. Padhiari (2006). Antibacterial activity of Cuscuta reflexa stem and Corchorus olitorious seed. Fitoterapia 77:589-91.

Putnam, A. R. and C. S. Tang (1986). Allelopathy: State of the science, p. 1-17. In: The Science of Allelopathy. Putnam, A R. and C. S. Tang (Eds.). Wiley Interscience, New York.

Quayyum, H. A., A. U. Malik and P. F. Lee (1999). Allelopathic potentials of aquatic plants associated with wild rice (Zizania palustris). I. Bioassay with plant and lake sediment samples. Journal of Chemical Ecology 25:209-218.

Reigosa, M. J., A. Sanchez-Moreiras and L. Gonzales (1999). Ecological approach in Allelopathy. Critical. Review in Plant Science 18:577-608.
Rice, E. L. (1979). Allelopathy-An update. Bot. Rev. 45:15109.

Rice, E. L. (1984). Allelopathy Academic Press, London.

Rice, E. L. (1992). Allelopathic effects on Nitrogen cycling, pp. 31-58. In: Allelopathy: Basic and Applied Aspects. Rivzi, S. and J. H. V. Rizvi (Eds.). Chapman and Hall, London.

Sharaf, A. and S. A. R. Negm. (2005). Pharmacological study of Corchorus olitorious L. seeds with special reference to its cardiovascular activity. Plant foods for Human Nutrition 17:305-312.

Sin Clair, J. R. (1990). Nitrogen Influence on the Physiology of Crop Yield, p. 41-55. In: Theoretical Production Ecology. Van Laar (Eds.). Pudos. Wageningen Netherlands.

Singhvi, N. R. and K. D. Sharma. (1984). Allelopathic effects of Ludwigia adscendens L. and Ipomoea aquatica Forsk. on seedling growth of pearl millet (Pennisetum typhoidium Rich.). Trans. ISDT UCDS. 9:95-100.

Stinson, K. A., R. M. Campell, G. C. Thelen, S. G. Hallet, D. Prati and J. N. Klironomos (2006). Invasive plant suppresses the growth of native tree seedlings by disrupting below ground mutualisms. Biology Plos Biol. 5:727-731.

Wogu, A. and R. E. Ugborogho (2000). Seed morphology, germination and seedling characters in Ludwigia species (Onagraceae) in Nigeria as aids to identification. Seed Science Technology 28:657-697.

Zardini, E. M., H. Gu and P. H. Raven (1991). On the separation of 2 species within the Ludwigia uruguayensis Complex (Onagraceae). Systematic Botany 16:242-244. 